\title{
Five native tree species and manioc under slash-and-mulch agroforestry in the eastern Amazon of Brazil: plant growth and soil responses
}

\author{
Aaron H. Joslin • Daniel Markewitz • \\ Lawrence A. Morris • Francisco DeAssis Oliveira • \\ Ricardo O. Figueiredo $\cdot$ Oswaldo R. Kato
}

Received: 13 August 2008/Accepted: 9 October 2010/Published online: 16 November 2010

(C) Springer Science+Business Media B.V. 2010

\begin{abstract}
Throughout the Amazon of Brazil, manioc (Manihot esculenta) is a staple crop produced through slash-and-burn agriculture. Nutrient losses during slash-and-burn can be large and nutrient demand by food crops so great that fields are often abandoned after two years. In recent decades, farmers have reduced the fallow phase from 20 to $\sim 5$ years, limiting plant nutrient accumulation to sustain crop yields. Improved fallows through simultaneous planting of trees with food crops may accelerate nutrient re-accumulation. In addition, slash-and-mulch technology may prevent loss of nutrients due to burning and mulch decomposition may serve as a slow-release source of nutrients. This study in Pará, Brazil, in a 7-year-old secondary forest following slashing and mulching of the vegetation, involved two main plot treatments (with and without $\mathrm{P}$ and $\mathrm{K}$ fertilizers) and
\end{abstract}

\footnotetext{
A. H. Joslin · D. Markewitz $(\bowtie) \cdot$ L. A. Morris Warnell School of Forestry and Natural Resources, The University of Georgia, Athens, GA 30602, USA e-mail: dmarke@warnell.uga.edu

F. DeAssis Oliveira

Institute of Agricultural Sciences (ICA), University of Agricultural Sciences of Amazonia (UFRA), 2501 Perimetral Avenue, PO Box 917, Belem, PA 66077530, Brazil

e-mail: francisco.oliveira@ufra.edu.br

R. O. Figueiredo · O. R. Kato

Embrapa Amazonia Oriental, Belem, Brazil

e-mail: ricardo@cpatu.embrapa.br
}

two sub-plot treatments (with or without a $\mathrm{N}_{2}$-fixer Inga edulis). A mixed-culture of trees and manioc was planted in all plots. $\mathrm{P}$ and $\mathrm{K}$ fertilizer increased tree mortality due to weed competition but growth of surviving trees in four of the five tree species tested also increased as did biomass production of manioc. In the $\mathrm{N}_{2}$-fixer treatment trends of greater growth and survival of four of five tree species and manioc biomass were also observed. Fertilization increased the biomass of competing vegetation, but there was a fertilizer by $\mathrm{N}_{2}$-fixer interaction as I. edulis caused a reduction in competing biomass in the fertilized treatment. After one year, fertilization increased decomposition of the mulch such that $\mathrm{Ca}, \mathrm{Mg}$, and $\mathrm{N}$ contents within the mulch all decreased. In contrast, $\mathrm{P}$ and $\mathrm{K}$ contents of mulch increased in all treatments. No influence of the $\mathrm{N}_{2}$-fixer on $0-10 \mathrm{~cm}$ soil $\mathrm{N}$ contents was observed. Two years after establishment, this agroforestry system succeeded in growing a manioc crop and leaving a well-maintained tree fallow after the crop harvest.

Keywords Mixed culture - Fertilization · Native species $\cdot$ Slash-and-mulch

\section{Introduction}

In the Bragantina region of Northeast Pará, Brazil the staple food crop cassava or manioc, locally known as 'mandioca' (Manihot esculenta Crantz), is produced 
by practicing swidden-fallow agriculture where forest vegetation is slashed and burned to prepare the land for cultivation. Unfortunately, the highly-weathered soils in this region are low in available nutrients, particularly $\mathrm{N}, \mathrm{P}$, and $\mathrm{K}$, which can restrict crop productivity under low-input agriculture. The ash of burned vegetation fertilizes the subsequent crops, which are cultivated for up to two years before farmers abandon the plot to secondary forest succession. Sustainability of swidden-fallow agriculture depends largely upon the length of secondary forest succession in which nutrient accumulation can occur through shallow and deep root uptake (Stanley and Montagnini 1999). Farmers in Northeast Pará are reducing the length of time in fallow vegetation from 20 to $<5$ years (Gehring et al. 1999), thereby reducing the fallow-cropping period ratio to levels that may be too low to sustain the system (Metzger 2002).

Slash-and-burn farming also reduces the nutrient capital of the system due to element losses through volatilization, oxidation, ash dispersion, erosion, and leaching (Hölscher 1997). Slash-and-mulch technology can eliminate losses from fire through the use of a mulching tractor (Kato et al. 1999), which fells the forest, chops the vegetation, and lays it on the surface. This method adds all of the nutrient components to the surface, which are then potentially available for future plant uptake (Denich et al. 2004). High C:N ratios of this felled material due to a $69-79 \%$ contribution from wood biomass and only $8-10 \%$ from leaves may initially immobilize nutrients, however, making fertilization necessary for sufficient crop growth. Enrichment plantings with $\mathrm{N}_{2}$-fixing trees may also serve to decrease $\mathrm{C}: \mathrm{N}$ ratios and increase nutrient availability.

The use of $\mathrm{N}_{2}$-fixing and other fast-growing trees may augment fallow re-growth. Use of Inga edulis, an $\mathrm{N}_{2}$-fixing legume, has generated greater biomass than control fallows in this region (Brienza 1999). $\mathrm{N}_{2}$-fixing trees can also be used during the cropping phase as a source of green manure for manioc and then left to stimulate secondary forest succession, though they can have a negative effect on crops through competition (Sanchez 1995). High productivity and slow foliar decomposition (Zech et al. 1997) has made I. edulis a particularly desirable $\mathrm{N}_{2}$-fixer for agroforestry projects.

In addition to $\mathrm{N}$ limitation, phosphorus may also be a major limiting nutrient to plant production in upland soils of the eastern Amazon (Davidson et al.
2004; Gehring et al. 1999). Adding mulch can immobilize $\mathrm{P}$ during initial stages of decomposition (Baggie et al. 2004). Whether additions of inorganic $\mathrm{P}$ fertilizer can ameliorate any immobilization or even enhance rates of mulch decomposition is unknown. Furthermore, the effects of mulch on weed competition are uncertain (Gallagher et al. 1999).

Fallow management through small inputs of fertilizer and/or planting of selected trees species may contribute to nutrient accumulation in the ensuing secondary forest and enhance ecological values. Moreover, selection of appropriate species can provide owners of small landholdings an opportunity to produce marketable commodities such as cattle fodder, posts and small timber at the end of one or two swidden cycles that would not normally occur on these sites. The objectives of this research were to evaluate the potential of planted tree fallows under slashed and mulched secondary forest in the presence and absence of $\mathrm{P}$ and $\mathrm{K}$ fertilization and $\mathrm{N}_{2}$-fixing trees to enhance food crop yield and economic value of the system. The hypotheses tested were (1) P and $\mathrm{K}$ fertilization and interplanting of $\mathrm{N}_{2}$-fixing trees would accelerate mulch decomposition and increase topsoil nutrient contents and (2) that all tree species and manioc would respond positively to $\mathrm{P}$ and $\mathrm{K}$ fertilizers and interplanting with an $\mathrm{N}_{2}$-fixer. We report data of the two first years of tree survival and growth, the impact of the system on soil properties, and data from the first manioc harvest.

\section{Materials and methods}

Site description

The research site is at the experimental farm of the Universidade Federal Rural da Amazônia (UFRA) in the Municipality of Igarapé Açu $\left(1^{\circ} 07^{\prime} 41^{\prime \prime} \mathrm{S}\right.$, $47^{\circ} 47^{\prime} 15^{\prime \prime}$ W) $110 \mathrm{~km}$ East of Belém, Pará, Brazil. This region, known as the Bragantina, is one of the oldest continually inhabited agricultural areas in the Amazon and the landscape is now completely dominated by human activities and secondary forests. Soil great groups in the municipality of Igarapé Açu are predominantly Kandiudults, Kanhapludults, Kandiaquults, and Kanhapluaquults; all represent soils with argillic horizons but are differentiated by drainage. In the Brazilian classification these soils 
would be in the Argisolos and Gleisolos orders. Igarapé Açu has an average annual temperature of $26^{\circ} \mathrm{C}$ and annual rainfall of $2500 \mathrm{~mm}$ (Kato et al. 1999) with a dry season from July to November.

\section{Species descriptions}

The tree species utilized are native to forests of the Bragantina region. Inga edulis Mart. (Mimosoideae) is the only demonstrated $\mathrm{N}_{2}$-fixer among the tested species. I. edulis is widely used in agroforestry systems (AFS) in the Americas because it is acid-soil tolerant, has high rates of $\mathrm{N}_{2}$-fixation, and high $\mathrm{N}$ content in its litter. It has high survival and good production in both monoculture and multi-species plantings (Kettler 1997). Parkia multijuga Benth. is a Mimosoideae with uncertain nodulating properties (Moreira et al. 1992). It is a strong light-demander, a commercially valuable species, and has a substantial role as a secondary forest tree in Peruvian AFS (Peck and Bishop 1992). Schizolobium amazonicum Hub. ex Ducke. (Caesalpinioideae) is a short-lived, non-nodulating, early successional pioneer species (Peña-Claros 2003). It has beneficial commercial timber properties and rapid growth (Yamada and Gholz 2002). Ceiba pentandra (L.) Gaertn. (Bombacaceae) is a fastgrowing heliophyte (Lorenzi 2002) with high lumber value that has been harvested heavily and is commonly used in paper-pulp production (Pinedo-Vasquez et al. 2001). Cedrela odorata Linn. (Meliaceae) is a strong light demander but considered a slow-growing species (Pinedo-Vasquez et al. 2001). C. odorata has one of the highest commercial timber values in Brazil (Lorenzi 2002) and is an important species for shading coffee in Central America (Navarro et al. 2004). Manihot esculenta Crantz (Euphorbiaceae) is native to South America, and is a staple crop throughout the tropics of the world. Bitter manioc grows well in very acid, nutrient poor soils without external inputs, although yields may begin to decline with consecutive cropping due to K deficiency (Howeler 2002).

\section{Plot establishment}

In March of 2005, a one-hectare site of previously cultivated 7-year-old secondary forest was cleared with a TRITUCAP mulching tractor (Denich et al. 2004) that evenly distributed the macerated above-ground biomass over the soil surface. Four experimental blocks that run north-south across the site were established (Fig. 1). Since we expected to observe large differences due to fertilization each block was divided into two main plots, one received fertilization and one did not. These main plots were split into two subplots. One subplot was planted with a species mix that included $\mathrm{N}_{2}$-fixing species and the other was planted without inclusion of $\mathrm{N}_{2}$-fixing species. Each subplot measured $24 \times 24 \mathrm{~m}$. The main plot fertilization treatments were randomly assigned within each block and then $\mathrm{N}_{2}$-fixer addition was assigned randomly within the fertilizer or no fertilizer main plots. The main-plot fertilizer treatments consisted of no fertilization $(\mathrm{PK}-)$ or phosphorus and potassium fertilization $(\mathrm{PK}+)$. Phosphorus, as concentrated super phosphate, was surface applied in a $0.5 \mathrm{~m}$ radius around each tree at a rate of $73 \mathrm{~g} /$ tree, equivalent to $20 \mathrm{~kg} \mathrm{ha}^{-1}$ elemental $\mathrm{P}$. Potassium was applied as $\mathrm{KCl}$ at a rate of $36 \mathrm{~g} /$ tree in a similar manner, a rate equivalent to $25 \mathrm{~kg} \mathrm{ha}^{-1}$

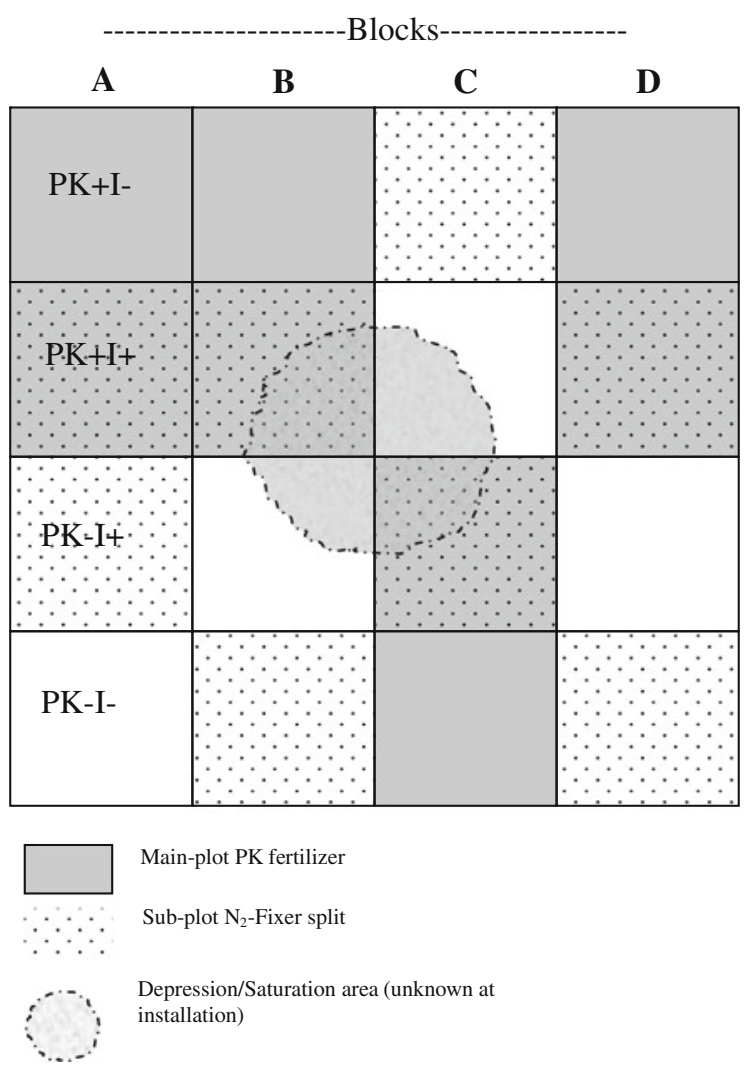

Fig. 1 Experimental design for fertilization and $\mathrm{N}_{2}$-fixer Agroforestry System trial in the eastern Amazon of Brazil 
elemental K. The split-plot treatment consisted of planting S. amazonicum, C. odorata and C. pentandra together (I-), or in combination with the $\mathrm{N}_{2}$-fixing species I. edulis as well as with the Mimosoideae P. multijuga (I+). Species within the Mimosoideae are generally $\mathrm{N}_{2}$-fixing, but $P$. multijuga has uncertain nodulating properties. To avoid introducing a potential $\mathrm{N}_{2}$-fixer in the non $\mathrm{N}_{2}$-fixer plots, we planted this species only in the $\mathrm{N}_{2}$-fixer plots.

In the topsoil (0-10 and 10-20 cm depth increments), physical and chemical (Table 1) properties across the blocks were quite uniform at establishment with coefficients of variation $<20 \%$ for all parameters at both depths. On this site, the topsoil was relatively sandy $(\sim 70 \%)$, moderate in organic matter (1-2\%), mildly acidic ( $\sim \mathrm{pH} 4.3)$, and of low charge (1-7 $\mathrm{cmol}_{\mathrm{c}} \mathrm{kg}^{-1}$ ). Soil bulk density was measured on a plot basis at establishment and demonstrated limited variation with a mean value of $1.2 \pm 0.1 \mathrm{~g} \mathrm{~cm}^{-3}$. Initial total $\mathrm{N}$ concentrations in $0-10 \mathrm{~cm}$ averaged $( \pm \mathrm{SE})$ $1.1 \pm 0.08 \mathrm{~g} \mathrm{~kg}^{-1}$ (Table 1) and were slightly lower at the surface than at $10-20 \mathrm{~cm}$ depth $(1.4 \pm 0.16)$.

Each split-plot contained six rows of trees with 13 trees per row for a total of 78 trees per 0.06 ha plot (1354 trees $\mathrm{ha}^{-1}$ ). Within each row, $1.8 \mathrm{~m}$ spacing was utilized with $4.0 \mathrm{~m}$ between rows of trees. Seedlings were produced at a local nursery (AIMEX) and were 3-5 months in age depending on species at the time of planting. Seedlings were culled to minimize variance in seedling size. In both treatments, species were alternated continuously within rows in a systematic fashion so that two of the same species could not occur together within a row. A 2-m buffer area was established between plots and a $1.5 \mathrm{~m}$ buffer was used between blocks.

In July of 2005, bitter manioc was planted at $1 \times 1 \mathrm{~m}$ spacing in all treatments, at a planting density of 10,000 stems $^{-1}$. Rows of manioc were planted with $0.5 \mathrm{~m}$ spacing on both sides of each row of trees and the nearest row of manioc. Mature manioc plants were cut into $10 \mathrm{~cm}$ segments and used as planting stock. Fallow vegetation is traditionally slashed at the beginning of the dry season and burned after drying, while planting of manioc coincides with the onset of the rains in December or January. Planting was not completed until July for this project; however, the thick mulch layer produced by the mulching tractor maintains soil moisture at levels acceptable for manioc growth (Denich et al. 2004). 
Growth and biomass assessment

The initial size of the nursery-grown seedlings was determined by randomly sampling $10 \%$ of the trees before planting for measurement of ground-line diameter (GLD) and height. Then, in March of 2006, July 2006, and July 2007 survival, height, and GLD were recorded for all trees of each species. GLD was measured using digital calipers and height was measured using a $3 \mathrm{~m}$ pole or hypsometer. In March 2007, all I. edulis that were above $2 \mathrm{~m}$ height were pruned at $\sim 1.8 \mathrm{~m}$ and pruned material was left on site around the base of the tree.

At the time of planting in June of 2005 there was no appreciable above-ground biomass of weed competition or manioc as the site had recently been mulched and planted. In June 2006 manioc and above-ground weed competition biomass were collected. Each plot was divided into four quadrants and each quadrant was divided into twenty potential sampling sectors. A $1 \mathrm{~m}^{2}$ sampling frame constructed from PVC tubing was placed within a randomly selected sector within each quadrant. All living vegetation within the vertical plane above the PVC tubing was collected. This procedure was used to collect all competing vegetation that was neither manioc nor planted tree species. During Year 1 tree measurement, all competing vegetation on site above the soil surface was hand-cut and left on site. This was the only time such weeding was preformed.

In March 2007, manioc biomass was re-measured within an $8 \times 8 \mathrm{~m}$ sampling plot placed in the center of each treatment plot. All manioc biomass within the vertical plane of the sampling plot was collected and separated into aboveground (leaf and stem) and belowground (tuber) components. All manioc biomass was weighed fresh in the field using a hanging spring balance. Sub-samples were taken to UFRA in Belém and dried in a forced-air oven at $60^{\circ} \mathrm{C}$ until a constant weight was achieved.

\section{Mulch sampling}

In June 2005, the initial mulch layer was sampled to quantify the initial mass and nutrient contents of the mulch. A $25 \times 25 \mathrm{~cm}$ frame was placed randomly within each of four quadrants within each plot and all mulched biomass within this frame was collected down to the mineral soil surface. Mulch material was dried to a constant weight in a forced-air oven at $60^{\circ} \mathrm{C}$. Mulch material was analyzed at UFRA using total Kjeldahl Nitrogen procedures for N (Bremmer and Mulvaney 1982) and nitric-perchloric acid digest for $\mathrm{P}, \mathrm{K}, \mathrm{Ca}$, and $\mathrm{Mg}$ (Hossner 1996). Phosphorus was measured using molybdate blue chemistry on a manual spectrophotometer; $\mathrm{K}$ by flame photometry; and $\mathrm{Ca}$ and $\mathrm{Mg}$ by atomic absorption spectrophotometry. In June 2006, the same procedures were followed to estimate changes in mulch mass and nutrient content.

Soil sampling

In June 2005, prior to fertilization, soil cores were taken from each of the four quadrants within each plot; soil cores were divided into $0-10$ and $10-20 \mathrm{~cm}$ depths. The four cores were composited by depth within each plot. All plots of the same block were then further composited by depth for a single block sample (Table 1). Samples were analyzed for total N, extractable $\mathrm{P}, \mathrm{K}, \mathrm{Ca}$, and $\mathrm{Mg}$, and $\mathrm{pH}$ at UFRA while organic material and particle size (i.e., sand, silt, and clay) were analyzed at the Soil Analysis Laboratory of Embrapa Amazônia Oriental in Belém. Soil N was analyzed using total Kjeldahl procedures; $\mathrm{P}$ and $\mathrm{K}$ were extracted using Mehlich-1; $\mathrm{Ca}$ and $\mathrm{Mg}$ were extracted with $1 \mathrm{M} \mathrm{KCl}$. Organic matter was by loss on ignition (Nelson and Sommers 1996) and particle size by the hydrometer method (Gee and Bauder 1986). Soil bulk density was also characterized by block using a 5-cm diameter core (Blake and Hartge 1986). In June 2006, in conjunction with mulch sampling, the soils were re-sampled and the same procedures were followed except bulk density was not re-measured and samples were retained separately by plot to estimate changes in nutrient concentrations and contents.

\section{Statistical analysis}

Analysis of variance (ANOVA) was used to analyze the study as a two-factor split-plot experiment with four complete blocks. Fertilizer treatment with and without $\mathrm{P}$ plus $\mathrm{K}$ additions were the main-plot treatments $(n=4)$ and treatments with or without the presence of I. edulis and P. multijuga were the sub-plot treatments $(n=4)$. Time was also treated as a split-split-plot for tests of repeated measures where 
appropriate, such as for re-sampling of mulch. Where significant differences were indicated by ANOVA, mean separation was conducted across treatment combinations using Tukey's adjustment.

\section{Results}

$\mathrm{N}_{2}$-fixer treatment

Both I. edulis and P. multijuga were planted as part of the $\mathrm{N}_{2}$-fixer treatment. During the 2-year period after planting, abundant nodules were observed on the roots of I. edulis but were never observed on P. multijuga roots. As such, throughout the results and discussion we often refer to the $\mathrm{N}_{2}$-fixer treatment as a $\mathrm{N}_{2}$-fixer or specifically as a response to I. edulis.

Tree survival

Mean survival across all species after Year 1 was higher $(P=0.002)$ in unfertilized $(\mathrm{PK}-)$ plots than in fertilized $(\mathrm{PK}+)$ plots (Table 2). A trend of increased survival $(P=0.10)$ in the $\mathrm{N}_{2}$-fixer was also observed but there was no Fert $\times \mathrm{N}_{2}$-fixer interaction $(P=0.16)$. After Year 2 results were similar although percent survival had declined in most treatments such that there was a significant effect of year $(P=0.01)$. After Year 2, all-species mean survival was still higher $(P<0.011)$ in unfertilized $(\mathrm{PK}-)$ plots and had a similar tendency with an $\mathrm{N}_{2}$-fixer $(P=0.10)$. The greater all-species mean survival with the $\mathrm{N}_{2}$-fixer results partly from the good survival of I. edulis (Table 2).

Growth responses

Fertilization had a positive effect $(P<0.01)$ on GLD and height growth of all tree species except P. multijuga while the presence of I. edulis did not have a significant effect on any species (Figs. 2 and 3 ) and there was no significant interaction. Trends of increased biomass were observed on fertilized plots and in the presence of I. edulis for manioc stems and manioc tubers (Fig. 4) beginning in Year 1. Twenty months after planting manioc, the dry weight of manioc leaf + stem production $(P=0.01)$, manioc tuber dry-weight biomass $(P=0.03)$ and total dryweight biomass $(P=0.01)$ were greater with $\mathrm{P}$ plus $\mathrm{K}$ fertilization than without (Fig. 4). There was, however, no significant effect of $\mathrm{N}_{2}$-fixer on total manioc biomass, although there was a significant interaction $(P=0.039)$. Without fertilization, manioc leaf + stem, tuber and total dry-weight biomass

Table 2 Percent survival (mean \pm 1 SE) of five species of trees native to the Amazon grown under different treatments 12 and 24 months after planting in June 2005 in Igarapé Açu, Pará, Brazil

\begin{tabular}{|c|c|c|c|c|c|}
\hline \multirow[t]{2}{*}{ Age (months) } & \multirow[t]{2}{*}{ Species } & \multicolumn{4}{|l|}{ Treatment } \\
\hline & & $\mathrm{PK}-\mathrm{I}-(\% \pm 1 \mathrm{SE})$ & $\mathrm{PK}-\mathrm{I}+(\% \pm 1 \mathrm{SE})$ & $\mathrm{PK}+\mathrm{I}-(\% \pm 1 \mathrm{SE})$ & $\mathrm{PK}+\mathrm{I}+(\% \pm 1 \mathrm{SE})$ \\
\hline \multirow[t]{6}{*}{12} & Inga edulis & & $98.8 \pm 0.7 \mathrm{aA}^{\mathrm{a}}$ & & $51.3 \pm 6.1 \mathrm{bA}$ \\
\hline & Parkia multijunga & & $87.9 \pm 5.1 \mathrm{aA}$ & & $14.3 \pm 5.5 \mathrm{bA}$ \\
\hline & Cadrela odorata & $79.8 \pm 3.6 \mathrm{aA}$ & $80.0 \pm 4.1 \mathrm{aA}$ & $6.9 \pm 3.4 \mathrm{bA}$ & $5.3 \pm 6.3 \mathrm{bA}$ \\
\hline & Schizolobium amazonicum & $63.6 \pm 4.4 \mathrm{aA}$ & $65.8 \pm 5.9 \mathrm{aA}$ & $51.5 \pm 3.4 \mathrm{aA}$ & $43.6 \pm 10.3 \mathrm{aA}$ \\
\hline & Ceiba pentandra & $97.1 \pm 1.4 \mathrm{aA}$ & $100 \pm 0.0 \mathrm{aA}$ & $37.4 \pm 6.7 \mathrm{bA}$ & $25.0 \pm 10.4 \mathrm{bA}$ \\
\hline & All species mean & $80.1 \pm 3.6 \mathrm{aA}$ & $91.3 \pm 1.6 \mathrm{aA}$ & $32.0 \pm 4.4 \mathrm{bA}$ & $37.2 \pm 4.0 \mathrm{bA}$ \\
\hline \multirow[t]{6}{*}{24} & Inga edulis & & $91.9 \pm 3.3 \mathrm{aA}$ & & $44.4 \pm 5.9 \mathrm{bA}$ \\
\hline & Parkia multijunga & & $78.8 \pm 7.9 \mathrm{aA}$ & & $11.4 \pm 4.1 \mathrm{bA}$ \\
\hline & Cadrela odorata & $56.6 \pm 8.9 \mathrm{aA}$ & $57.5 \pm 7.5 \mathrm{aA}$ & $5.9 \pm 2.0 \mathrm{bA}$ & $0.0 \mathrm{bA}$ \\
\hline & Schizolobium amazonicum & $29.9 \pm 5.8 \mathrm{aB}$ & $21.0 \pm 6.1 \mathrm{aB}$ & $46.5 \pm 13.6 \mathrm{aA}$ & $43.6 \pm 7.7 \mathrm{aA}$ \\
\hline & Ceiba pentandra & $82.9 \pm 3.9 \mathrm{aA}$ & $82.9 \pm 4.9 \mathrm{aA}$ & $32.7 \pm 6.8 \mathrm{bA}$ & $20.0 \pm 8.2 \mathrm{bA}$ \\
\hline & All species mean & $56.3 \pm 5.2 \mathrm{aB}$ & $77.2 \pm 3.6 \mathrm{bB}$ & $27.5 \pm 3.2 \mathrm{cA}$ & $32.1 \pm 3.6 \mathrm{cA}$ \\
\hline
\end{tabular}

\footnotetext{
${ }^{a}$ Lower case letters indicate results for all means comparison within a row for each period Upper case letters indicate results for means comparison between years within a treatment Different letters for either comparison indicate $P<0.05$ for Tukey's honestly significant difference
} 


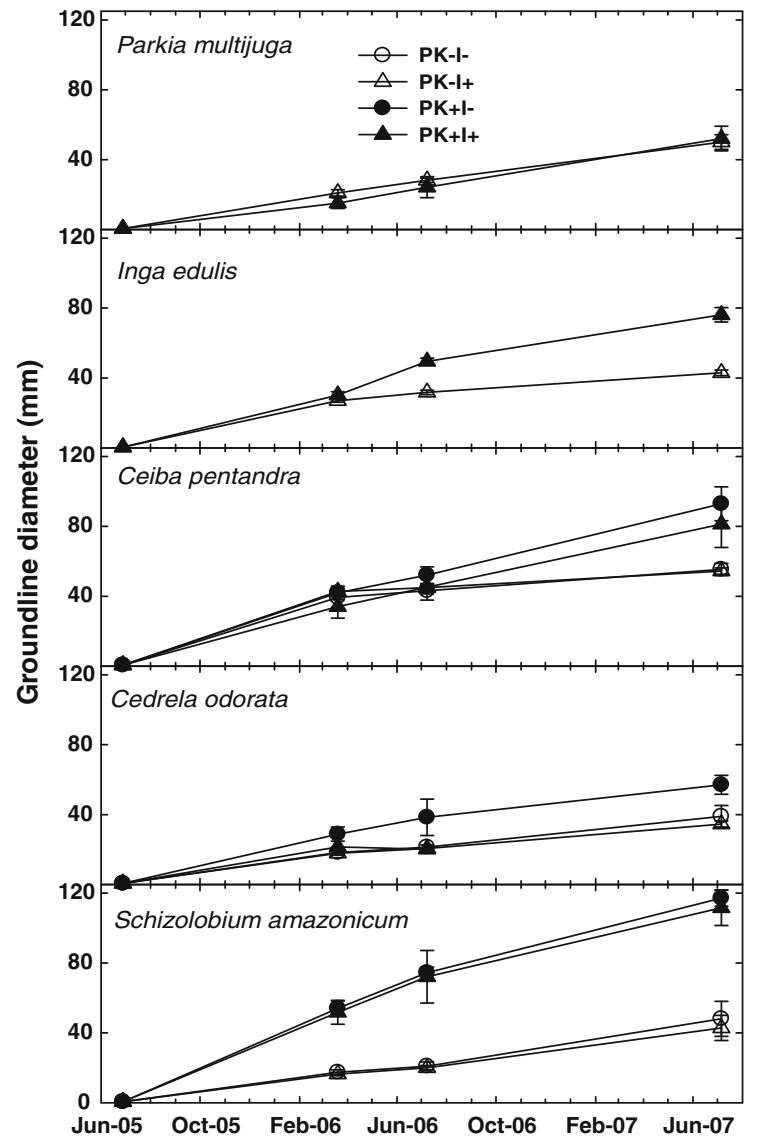

Fig. 2 Ground line diameter of five native tree species measured over a 2 -year period at 9,13 , and 25 months after planting in June 2005 in Igarapé Açu, Pará, Brazil. Treatments consist of a factorial combination of fertilization with $\mathrm{P}$ and $\mathrm{K}$ $(\mathrm{PK}+)$ or without fertilizer $(\mathrm{PK}-)$ planted with manioc and with 5 native tree species including I. edulis (I+) or of 3 native species without I. edulis (I-). Error bars represent $1 \mathrm{SE}$

was increased in the presence of I. edulis while with fertilization biomass production was not affected in the presence of I. edulis at 20 months (Fig. 4).

Competing weedy biomass increased with fertilization $(P=0.03)$ but there was no effect of the $\mathrm{N}_{2^{-}}$ fixer. There was also no significant fertilization by $\mathrm{N}_{2}$-fixer interaction (Fig. 5).

\section{Soil response}

At time of establishment there was an average of $54 \pm 4.8 \mathrm{Mg} \mathrm{ha}^{-1}$ of mulch biomass across the site with no significant differences by treatment (Fig. 6). One year after establishment mulch mass had decreased in all plots (i.e., effect for year; $P=0.004$ ) with a slight

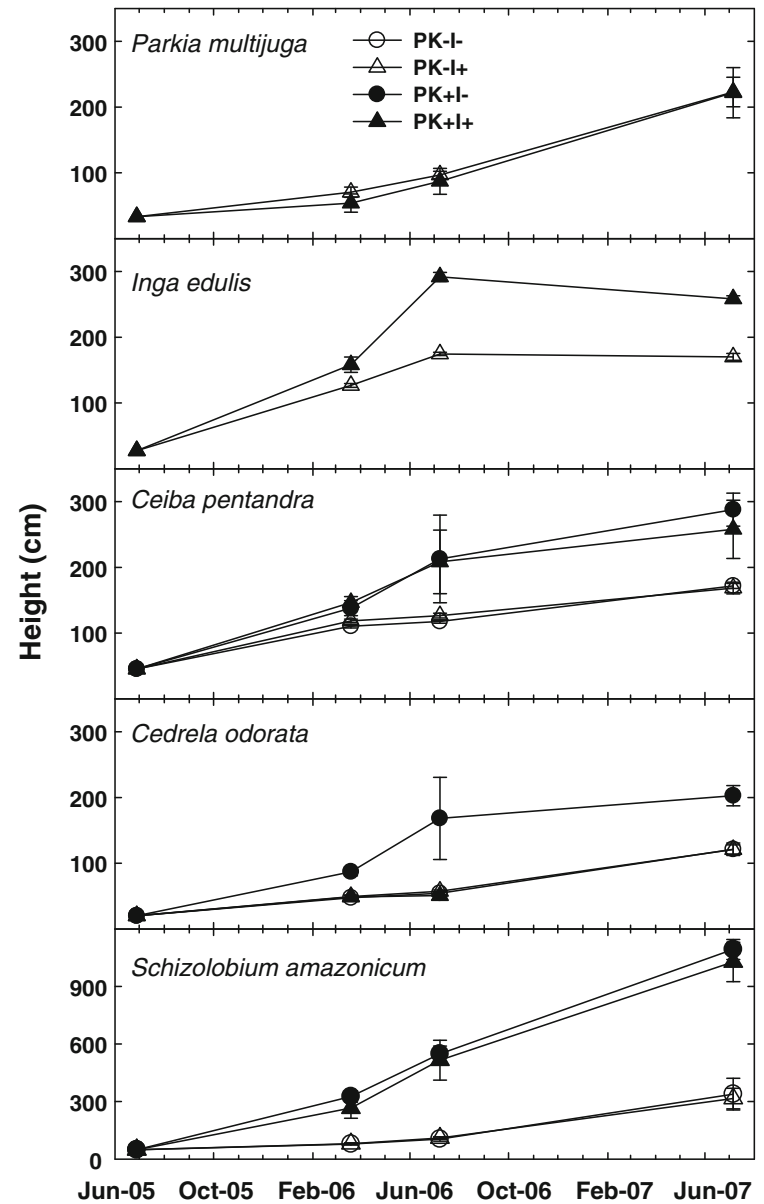

Fig. 3 Height of five native tree species during a 2-year period at 9, 13, and 25 months after planting in June 2005 in Igarapé Açu, Pará, Brazil. Treatments consist of fertilization with $\mathrm{P}$ and $\mathrm{K}(\mathrm{PK}+)$ or without fertilizer $(\mathrm{PK}-)$ planted with manioc and with 5 native tree species including I. edulis (I+) or of 3 native species without I. edulis (I-). Error bars represent 1 SE

effect for fertilizer $(P=0.057)$ but not $I$. edulis $(P=0.57)$. The $\mathrm{PK}+\mathrm{I}+$ treatment had the greatest mass loss on average (i.e., 70\%), which exceeded the $36 \%$ mass loss in the PK+I- treatment (Fig. 6). There was also a $45 \%$ mass loss from the mulch layer of the unfertilized treatments $(\mathrm{PK}-)$. The concentration of nutrients in mulch at establishment (Table 3) did not differ among treatments but had, in fact, increased for N, P, and K, and declined for Ca by the end of Year 1 (i.e., effect for year; $P \leq 0.05$ ). The combination of the mass loss and increased concentration, however, resulted in a non-significant decline $(P=0.23)$ in the content of $\mathrm{N}$ and no significant treatment effects after one year (Fig. 7). Phosphorus $(P=0.009)$ and 


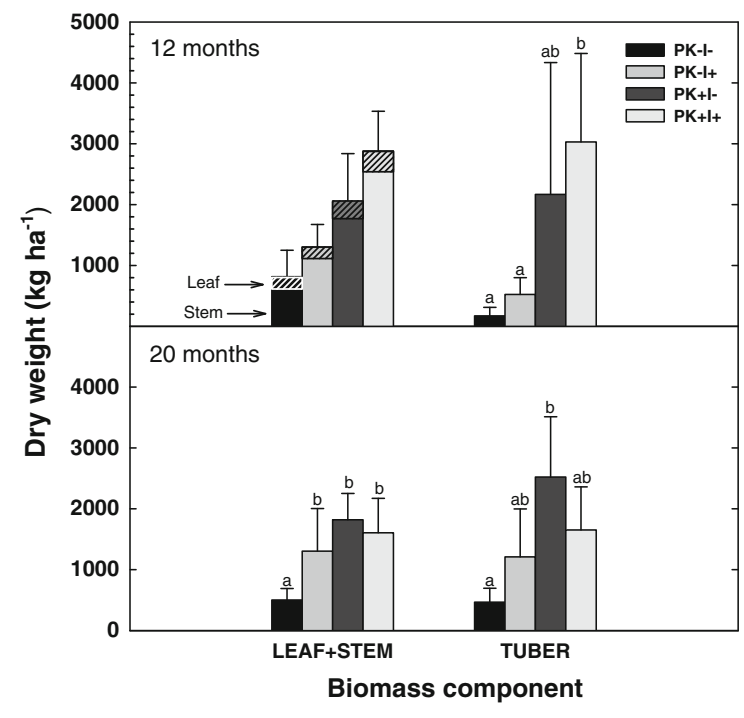

Fig. 4 Manioc dry weight (mean \pm SE) 12 and 20 months after planting in July 2005 in Igarapé Açu, Pará, Brazil. Treatments consist of a factorial combination of fertilization with $\mathrm{P}$ and $\mathrm{K}(\mathrm{PK}+)$ or without $(\mathrm{PK}-)$ and 5 native tree species with I. edulis (I+) or of 3 native tree species without I. edulis $(\mathrm{I}-)\{n=4\}$. Letters indicate significant differences for all means comparisons with Tukey's HSD within a period; absence of letters indicates no differences were significant

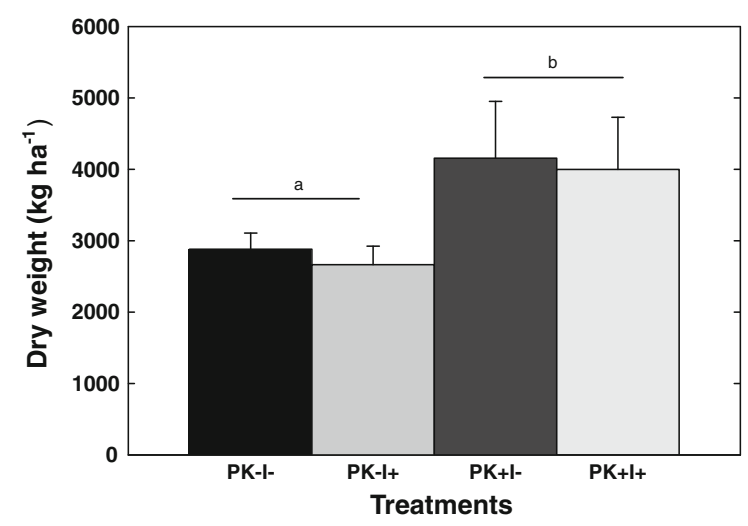

Fig. 5 Dry weight of competing vegetation (mean $\pm 1 \mathrm{SE}$ ) one year after planting in June 2005 in Igarapé Açu, Pará, Brazil. Treatments consist of a factorial combination of fertilization with $\mathrm{P}$ and $\mathrm{K}(\mathrm{PK}+)$ or without $(\mathrm{PK}-)$ and 5 native tree species with $I$. edulis $(\mathrm{I}+)$ or of 3 native tree species without $I$. edulis $(\mathrm{I}-)\{n=4\}$. Letters indicate a significant main fertilizer effect $(P<0.05)$; all means comparison with Tukey's HSD found no significant differences

$\mathrm{K}(P=0.09)$ increased in content while $\mathrm{Ca}(P=0.003)$ and $\mathrm{Mg}(P=0.01)$ contents declined. No effects of treatment were evident for any element at the end of Year 1 (Fig. 7).

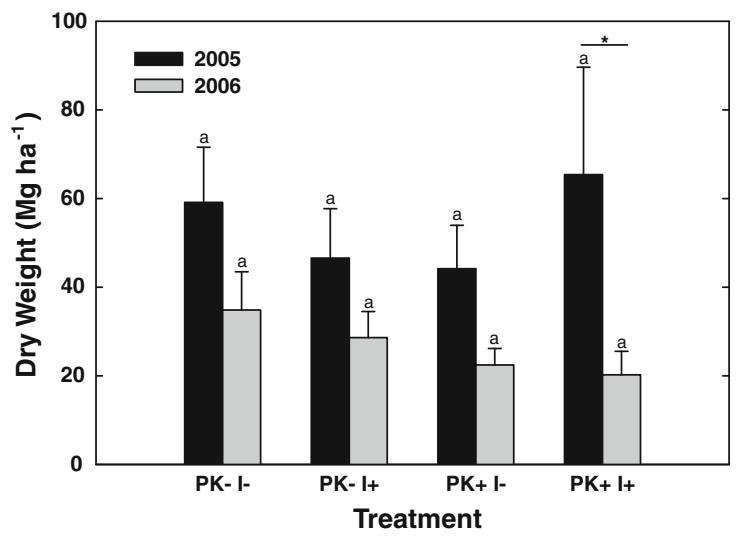

Fig. 6 Mass (mean $\pm 1 \mathrm{SE}$ ) of mulch layer by treatment at establishment in June 2005 and after one year in June 2006 in Igarapé Açu, Pará, Brazil. Treatments consist of a factorial combination of fertilization with $\mathrm{P}$ and $\mathrm{K}(\mathrm{PK}+)$ or without $(\mathrm{PK}-)$ and 5 native tree species with I. edulis (I+) or of 3 native tree species without $I$. edulis (I-) $\{n=4\}$. The main effect of year was significant $(P<0.05)$ while fertilization and $\mathrm{N}_{2}$-fixer were not. Letters indicate all mean comparison across treatments within a year and the asterisk indicates a significant difference between years

After one year, total soil $\mathrm{N}$ concentrations in the 0-10 cm layer exceeded $10-20 \mathrm{~cm}$ concentrations (Table 4). The mean exchangeable $\mathrm{K}$ values were $0.084 \pm 0.007 \mathrm{mg} \mathrm{kg}^{-1}$ in $0-10 \mathrm{~cm}$ and $0.055 \pm$ $0.004 \mathrm{mg} \mathrm{kg}^{-1}$ in 10-20 cm, which were slightly below those measured in the block composite (Table 1). Responses of $\mathrm{Ca}, \mathrm{Mg}$ and $\mathrm{pH}_{\mathrm{KCl}}$ were similar to those at initiation in that variation across blocks or plots was limited and there were no differences $(P>0.10)$ in the $0-10$ or $10-20 \mathrm{~cm}$ depths after one year between treatments (Table 4 ).

\section{Biomass nutrient concentrations and contents}

There were no significant differences in nutrient concentrations measured for manioc leaves $(26 \pm 3$, $2.9 \pm 0.8,7.5 \pm 1.0,10 \pm 2$, and $3.3 \pm 0.3 \mathrm{~g} \mathrm{~kg}^{-1}$; mean $\pm 1 \mathrm{SE}$ for $\mathrm{N}, \mathrm{P}, \mathrm{K}, \mathrm{Ca}$, and $\mathrm{Mg}$, respectively), stems $(10 \pm 3,3.1 \pm 0.6,5.9 \pm 0.6,6.0 \pm 0.3$, and $1.6 \pm 0.1 \mathrm{~g} \mathrm{~kg}^{-1}$, respectively) or tubers (4.3 \pm 1.3 , $2.4 \pm 0.3, \quad 5.5 \pm 1.5,2.1 \pm 0.8$, and $0.8 \pm 0.3 \mathrm{~g}$ $\mathrm{kg}^{-1}$, respectively) and no differences in nutrient contents for manioc leaves (Fig. 8). In manioc stems, however, $\mathrm{K}$ content was slightly greater $(P=0.09)$ with fertilization as was $\mathrm{N}$ content $(P=0.09)$ with $\mathrm{N}_{2}$-fixer. Manioc tubers also responded with greater 
Table 3 Nutrient concentration (mean \pm SE) of mulch layer at establishment in 2005 and after one year in Igarapé Açu, Pará, Brazil

\begin{tabular}{lllllll}
\hline Year & Treatment & $\mathrm{N}\left(\mathrm{g} \mathrm{kg}^{-1}\right)$ & $\mathrm{P}\left(\mathrm{g} \mathrm{kg}^{-1}\right)$ & $\mathrm{K}\left(\mathrm{g} \mathrm{kg}^{-1}\right)$ & $\mathrm{Ca}\left(\mathrm{g} \mathrm{kg}^{-1}\right)$ & $\mathrm{Mg}\left(\mathrm{g} \mathrm{kg}^{-1}\right)$ \\
\hline 2005 & PK-I- & $7.2 \pm 1.0 \mathrm{aA}$ & $0.26 \pm 0.01 \mathrm{aA}$ & $0.30 \pm 0.04 \mathrm{aA}$ & $6.8 \pm 0.5 \mathrm{aA}$ & $0.9 \pm 0.1 \mathrm{aA}$ \\
& $\mathrm{PK}-\mathrm{I}+$ & $5.2 \pm 0.3 \mathrm{aA}$ & $0.25 \pm 0.01 \mathrm{aA}$ & $0.22 \pm 0.04 \mathrm{aA}$ & $5.8 \pm 0.8 \mathrm{aA}$ & $0.7 \pm 0.04 \mathrm{aA}$ \\
& $\mathrm{PK}+\mathrm{I}-$ & $5.3 \pm 0.2 \mathrm{aA}$ & $0.26 \pm 0.02 \mathrm{aA}$ & $0.23 \pm 0.02 \mathrm{aA}$ & $5.8 \pm 0.5 \mathrm{aA}$ & $0.8 \pm 0.05 \mathrm{aA}$ \\
& $\mathrm{PK}+\mathrm{I}+$ & $5.9 \pm 0.9 \mathrm{aA}$ & $0.26 \pm 0.03 \mathrm{aA}$ & $0.23 \pm 0.05 \mathrm{aA}$ & $5.9 \pm 1.1 \mathrm{aA}$ & $0.8 \pm 0.1 \mathrm{aA}$ \\
2006 & $\mathrm{PK}-\mathrm{I}-$ & $8.7 \pm 1.3 \mathrm{aA}$ & $3.2 \pm 0.5 \mathrm{aB}$ & $2.2 \pm 0.7 \mathrm{aA}$ & $5.5 \pm 0.7 \mathrm{aA}$ & $0.7 \pm 0.2 \mathrm{aA}$ \\
& PK-I+ & $6.9 \pm 0.7 \mathrm{aA}$ & $2.4 \pm 0.6 \mathrm{aB}$ & $1.7 \pm 0.5 \mathrm{aA}$ & $4.9 \pm 0.5 \mathrm{aA}$ & $0.7 \pm 0.2 \mathrm{aA}$ \\
& PK $+\mathrm{I}-$ & $11.9 \pm 1.2 \mathrm{aB}$ & $2.9 \pm 0.6 \mathrm{aB}$ & $1.1 \pm 0.1 \mathrm{aA}$ & $6.5 \pm 0.7 \mathrm{aA}$ & $0.6 \pm 0.1 \mathrm{aA}$ \\
& $\mathrm{PK}+\mathrm{I}+$ & $9.9 \pm 2.2 \mathrm{aA}$ & $3.6 \pm 0.5 \mathrm{aB}$ & $1.8 \pm 0.4 \mathrm{aA}$ & $5.5 \pm 1.1 \mathrm{aA}$ & $0.7 \pm 0.1 \mathrm{aA}$ \\
\hline
\end{tabular}

${ }^{a}$ Lower case letters indicate results for all means comparison within a column for each year

Upper case letters indicate results for means comparison between years within a treatment

Different letters for either comparison indicate $P<0.05$ for Tukey's honestly significant difference

$\mathrm{Mg}$ content in the presence of the $\mathrm{N}_{2}$-fixer when fertilized. There were no significant interactions for any manioc component. In competing vegetation,

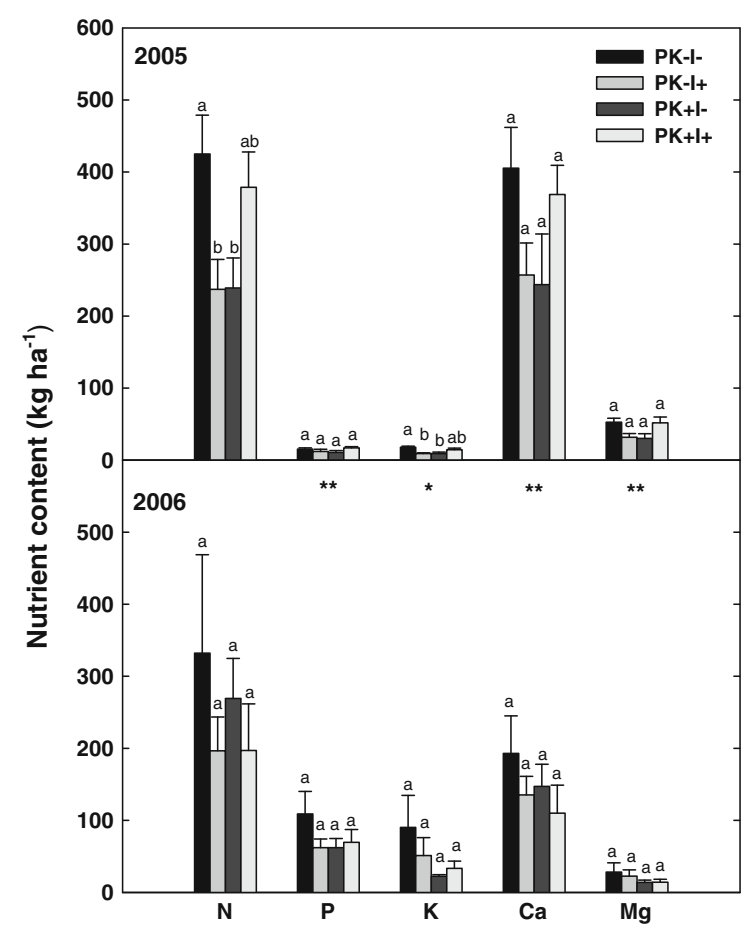

Fig. 7 Nutrient content (mean \pm 1 SE) of mulch layer at establishment in June 2005 and after one year in June 2006 in Igarapé Açu, Pará, Brazil. Treatments consist of a factorial combination of fertilization with $\mathrm{P}$ and $\mathrm{K}(\mathrm{PK}+)$ or without $(\mathrm{PK}-)$ and 5 native tree species with I. edulis $(\mathrm{I}+)$ or of 3 native tree species without I. edulis (I-) $\{n=4\}$. There was no main effect of fertilization or $\mathrm{N}_{2}$-fixer for any element but asterisks indicate significant main effects for year at the $P<0.005(* *)$ and $P=0.09(*)$. Letters indicate all means comparison among treatments within a year and element fertilization resulted in a greater concentration of $\mathrm{Ca}$ $(6.2 \pm 1.5$ vs $7.2 \pm 1.0, P=0.05)$ and nutrient contents were elevated in competing vegetation by fertilization for $\mathrm{K}$ and $\mathrm{Ca}(P=0.05)$ and slightly for $\mathrm{Mg}(P=0.09)$ (Fig. 9). There were no significant differences in competing vegetation nutrient contents due to the $\mathrm{N}_{2}$-fixer treatment (Fig. 9).

\section{Discussion}

Tree survival

Initially, survival of the trees was highly impacted by fertilization due to a $25 \%$ increase in weed competition (Fig. 5). The rapid growth of the competing vegetation increased shading for crop trees, a few of which were shade intolerant. Allelopathic effects or competition for water and nutrients by weeds are also possible (Hoffman and Carroll 1995). Survival of trees in the absence of fertilization was impressive, however, being $>60 \%$ for all species through Year 1.

Fertilization with $\mathrm{K}$ may have also contributed to mortality by stressing immature root systems of seedlings, which can lead to death during the dry season due to reduced drought tolerance (Jacobs et al. 2004). Planting season for crops and trees in the eastern Amazon region generally coincides with the onset of the rainy season in January. In this study, planting did not take place until late June, during the transition from the wet to dry season. In the fertilizer treatment, increased tree growth and thus demand for 
Table 4 Soil $\mathrm{pH}$ and nutrient concentrations (mean $\pm 1 \mathrm{SD}$ ) in June 2006 one year after establishment of treatments in Igarapé Açu, Pará, Brazil

\begin{tabular}{lllllllll}
\hline Treatment & $\begin{array}{l}\text { Depth } \\
(\mathrm{cm})\end{array}$ & $\mathrm{pH}(\mathrm{KCl})$ & $\begin{array}{l}\mathrm{N}^{\mathrm{a}} \\
\left(\mathrm{g} \mathrm{kg}^{-1}\right)\end{array}$ & $\begin{array}{l}\mathrm{P} \\
\left(\mathrm{mg} \mathrm{kg}^{-1}\right)\end{array}$ & $\begin{array}{l}\mathrm{K} \\
\left(\mathrm{cmol}_{\mathrm{c}} \mathrm{kg}^{-1}\right)\end{array}$ & $\begin{array}{l}\mathrm{Ca} \\
\left(\mathrm{cmol}_{\mathrm{c}} \mathrm{kg}^{-1}\right)\end{array}$ & $\begin{array}{l}\mathrm{Mg} \\
\left(\mathrm{cmol}_{\mathrm{c}} \mathrm{kg}^{-1}\right)\end{array}$ & $\begin{array}{l}\mathrm{Al} \\
\left(\mathrm{cmol}_{\mathrm{c}} \mathrm{kg}^{-1}\right)\end{array}$ \\
\hline PK-I- & $0-10$ & $4.3 \pm 0.2 \mathrm{a}$ & $1.8 \pm 0.8 \mathrm{a}$ & $4.6 \pm 0.3 \mathrm{a}$ & $0.08 \pm 0.01 \mathrm{a}$ & $2.2 \pm 1.0 \mathrm{a}$ & $0.34 \pm 0.12 \mathrm{a}$ & $0.35 \pm 0.11 \mathrm{a}$ \\
PK-I+ & & $4.4 \pm 0.2 \mathrm{a}$ & $1.5 \pm 0.2 \mathrm{ab}$ & $5.9 \pm 2.5 \mathrm{a}$ & $0.09 \pm 0.02 \mathrm{a}$ & $2.1 \pm 0.4 \mathrm{a}$ & $0.35 \pm 0.10 \mathrm{a}$ & $0.35 \pm 0.10 \mathrm{a}$ \\
PK+I- & & $4.3 \pm 0.2 \mathrm{a}$ & $1.4 \pm 0.4 \mathrm{~b}$ & $5.9 \pm 3.2 \mathrm{a}$ & $0.09 \pm 0.03 \mathrm{a}$ & $2.6 \pm 1.2 \mathrm{a}$ & $0.27 \pm 0.18 \mathrm{a}$ & $0.33 \pm 0.03 \mathrm{a}$ \\
PK+I+ & & $4.3 \pm 0.3 \mathrm{a}$ & $1.4 \pm 0.2 \mathrm{~b}$ & $5.7 \pm 3.9 \mathrm{a}$ & $0.09 \pm 0.06 \mathrm{a}$ & $1.7 \pm 0.7 \mathrm{a}$ & $0.23 \pm 0.07 \mathrm{a}$ & $0.31 \pm 0.05 \mathrm{a}$ \\
& & & & & & & & \\
PK-I- & $10-20$ & $4.1 \pm 0.2 \mathrm{a}$ & $1.3 \pm 0.6 \mathrm{a}$ & $1.9 \pm 0.8 \mathrm{a}$ & $0.06 \pm 0.01 \mathrm{a}$ & $0.4 \pm 0.3 \mathrm{a}$ & $0.13 \pm 0.06 \mathrm{a}$ & $0.91 \pm 0.74 \mathrm{a}$ \\
PK-I+ & & $4.2 \pm 0.3 \mathrm{a}$ & $1.1 \pm 0.1 \mathrm{a}$ & $2.2 \pm 0.8 \mathrm{a}$ & $0.06 \pm 0.01 \mathrm{a}$ & $0.5 \pm 0.1 \mathrm{a}$ & $0.15 \pm 0.05 \mathrm{a}$ & $0.53 \pm 0.09 \mathrm{a}$ \\
PK+I- & & $4.1 \pm 0.1 \mathrm{a}$ & $1.1 \pm 0.2 \mathrm{a}$ & $1.4 \pm 0.8 \mathrm{a}$ & $0.07 \pm 0.04 \mathrm{a}$ & $0.5 \pm 0.3 \mathrm{a}$ & $0.13 \pm 0.07 \mathrm{a}$ & $0.49 \pm 0.07 \mathrm{a}$ \\
PK+I+ & $4.4 \pm 0.5 \mathrm{a}$ & $1.0 \pm 0.0 \mathrm{a}$ & $3.1 \pm 1.2 \mathrm{a}$ & $0.07 \pm 0.01 \mathrm{a}$ & $0.2 \pm 0.0 \mathrm{a}$ & $0.04 \pm 0.05 \mathrm{a}$ & $0.49 \pm 0.04 \mathrm{a}$ \\
\hline
\end{tabular}

a Total Kjeldahl Nitrogen, Double-acid extracatable P, or KCl-extractable cations

$\mathrm{b}$ Lower case letters indicate results for all means comparison within a column and depth. Different letters within a column indicate $P<0.05$ for Tukey's honestly significant difference

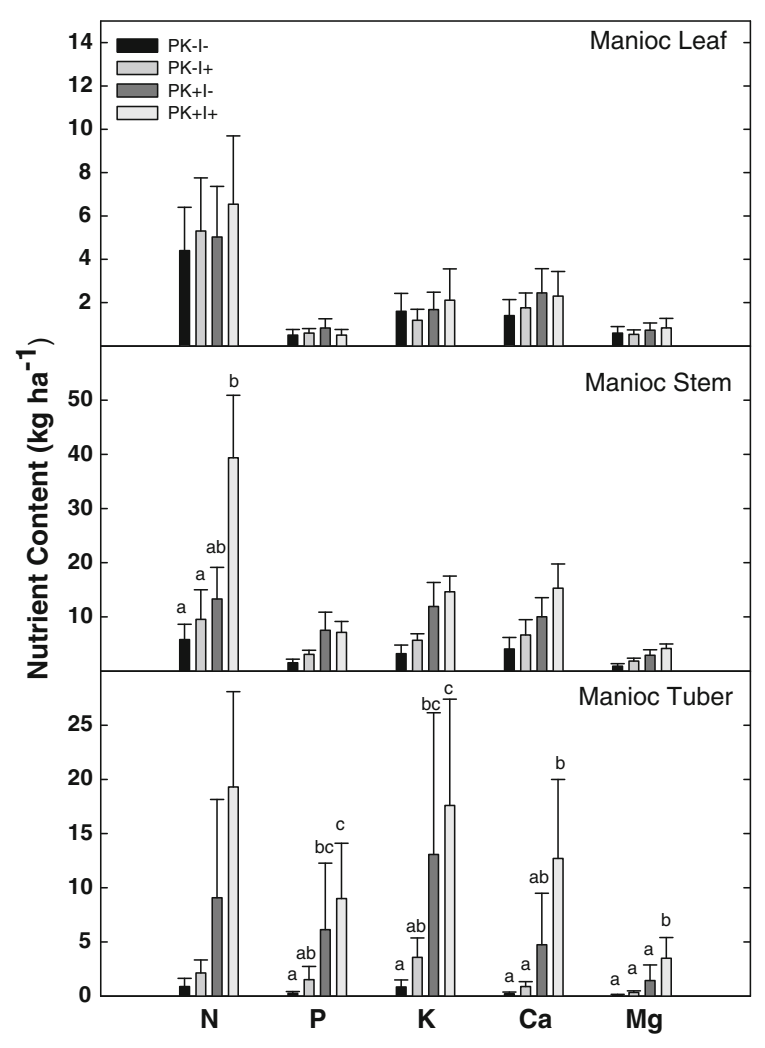

Fig. 8 Manioc nutrient content (mean $\pm 1 \mathrm{SE}$ ) one year after establishment in June 2005 in Igarapé Açu, Pará, Brazil. Treatments consist of a factorial combination of fertilization with $\mathrm{P}$ and $\mathrm{K}(\mathrm{PK}+)$ or without $(\mathrm{PK}-)$ and 5 native tree species with I. edulis (I+) or of 3 native tree species without I. edulis $(\mathrm{I}-)\{n=4\}$. Letters indicate significant differences for all means comparisons with Tukey's HSD; absence of letters indicates no differences were significant

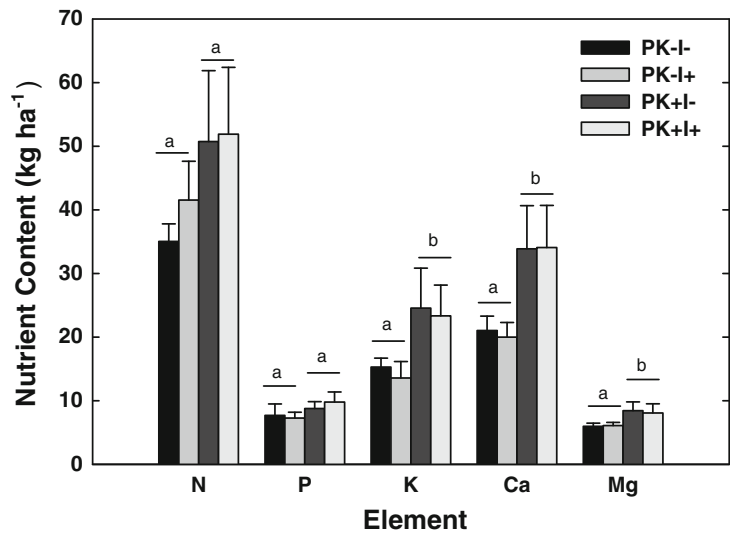

Fig. 9 Nutrient content (mean $\pm 1 \mathrm{SE}$ ) of competing vegetation one year after establishment in June 2005 in Igarapé Açu, Pará, Brazil. Treatments consist of a factorial combination of fertilization with $\mathrm{P}$ and $\mathrm{K}(\mathrm{PK}+)$ or without $(\mathrm{PK}-)$ and 5 native tree species with $I$. edulis (I+) or of 3 native tree species without I. edulis (I-) $\{n=4\}$. Letters indicate significant differences for the main fertilizer effect. There was no effect of the $\mathrm{N}_{2}$ Fixer and all means comparisons of treatments with Tukey's HSD also found no significant differences

moisture as well as increased weed competition apparently exceeded plant tolerances.

C. odorata, in particular, had exceptionally low survival in the fertilized treatment, $<10 \%$ after Year 1 and $<5 \%$ after Year 2. Hypsipila grandella damage was not noted on any $C$. odorata at the site. Davidson et al. (1998) showed similarly low survival of C. odorata with fertilization in Perú. C. odorata should only be fertilized well after the seedlings are established. In fact, Davidson et al. (1998) showed 
that among 15 native species planted, including both early and late successional species, fertilization reduced survival.

In contrast to mortality due to drought stress, poor soil drainage on portions of the site (Fig. 1) also decreased tree and manioc survival. A mild depression ( $<30 \mathrm{~cm}$ deep) approximately $25 \mathrm{~m}$ in radius, in the middle of the site, was poorly drained and periodically had water at the surface. Unfortunately, the mulch layer obscured this depression during plot establishment and thus a number of blocks and treatment plots were impacted. Survival was very low in this area.

\section{Growth response}

In general, height responses of the five species planted compares favorably to results reported elsewhere from the tropical Americas (Alegre et al. 2005; Brienza 1999; Browder and Pedlowski 2000; Camargo et al. 2002; d'Oliveira 2000). S. amazonicum was the most responsive to fertilization with $417 \%$ greater growth after one year. From Year 1 to 2, fertilized $S$. amazonicum also had the greatest absolute growth difference $(+490 \mathrm{~cm})$ and unfertilized $S$. amazonicum had the greatest percent difference $(+181 \%)$. As such, farmers could expect very vigorous growth from $S$. amazonicum. Height growth of I. edulis (67\%) and C. pentandra (40\%) also increased in response to fertilization while $C$. odorata had slower growth, although the slower growth of $C$. odorata should be balanced against its greater regional timber value.

Unlike the trees, total manioc tuber biomass (Fig. 4) was low relative to previous reports that ranged from 1 to $6 \mathrm{Mg} \mathrm{ha}^{-1}$ (El-Sharkawy 1993; Howeler and Cadavid 1983; Kato et al. 2005). It is not clear if the presence of competing vegetation (planted trees and "weeds") had an impact on biomass production of manioc as no treatments without trees or weeds were included in the trial. Previously, high manioc production in the Northeast of Brazil not only lacked trees but also had weed control and improved hybrids grown in monoculture (El-Sharkawy 1993; Kato et al. 2005). Brienza (1999), however, reported no loss of manioc tuber growth with the inclusion of $\mathrm{N}_{2}$-fixing trees at a number of planting densities (e.g., $1 \times 1,1 \times 2$ and $2 \times 2 \mathrm{~m})$.
Despite the generally low manioc tuber productivity at this site, manioc did respond to fertilization with increased manioc plant height but not leaf production (Fig. 4); manioc only carries leaves at its canopy level. The strong tree and manioc growth responses to fertilization indicate that $\mathrm{P}$ and/or $\mathrm{K}$ is limiting growth at this site. In contrast, the lack of a growth response to the $\mathrm{N}_{2}$-fixer I. edulis suggests that $\mathrm{N}$ may not be a limiting nutrient at this site (Gehring et al. 1999). It is also possible that two years was not sufficient time for the $\mathrm{N}_{2}$-fixing trees to influence $\mathrm{N}$ availability either through their roots or through litterfall and thus to increase growth of neighboring plants. Growth responses in I+ sup-plot treatments were not statistically significant at the end of Year 1 but there was a trend of greater growth in the presence of I. edulis. The presence of $\mathrm{N}_{2}$-fixers also increased biomass of manioc stems and tubers in both the fertilized and unfertilized treatments after one year (Fig. 4); a result different from Howeler (2002) that did not report significant differences for manioc tubers between control and NPK fertilization in Colombia until harvest in the third consecutive year of cropping.

Potential benefits of $\mathrm{N}_{2}$ fixation from I. edulis can be offset by competition for other resources such as water or light (Sanchez 1995). After Year 2, C. odorata responded negatively to the presence of I. edulis even in the presence of fertilization, suffering high mortality and suppressed growth. C. odorata is a strong light-demander and may have suffered from the increased shading by I. edulis due to its larger canopy with fertilization.

\section{Competing vegetation}

A potential benefit of slash-and-mulch technologies is weed suppression. Unfortunately, in this study, the mulch had little effect on competing woody vegetation since sprouts were able to establish under the mulch layer, contrary to earlier results of Rippin et al. (1994). Intense weed competition in the fertilized treatments undoubtedly had a negative impact on growth and survival of planted tree species as well as manioc. Species with slowly decomposing biomass, such as I. edulis, have also been reported to achieve greater weed control when compared to other legumes (Salazar et al. 1993). Competition suppression due to I. edulis could probably be expected to increase over time as trees age and deposit more 
biomass on the surface. This research indicates that I. edulis may have exerted some control on competition when not fertilized. In the fertilized treatment it appears that the addition of $\mathrm{P}$ and $\mathrm{K}$ was enough to free competing vegetation from nutrient limitations and competition from the planted trees.

\section{Nutrient cycling}

The observed initial N content of mulch (Fig. 6) was similar to a slash and mulch study in a 10 year-old secondary forest in Igarapé Açu that yielded $24 \mathrm{t} \mathrm{ha}^{-1}$ of mulched biomass with $332 \mathrm{~kg} \mathrm{ha}^{-1}$ of N (Kato et al. 1999). In the present study, after one year, $\mathrm{N}$ content decreased by $\sim 70 \pm 50 \mathrm{~kg} \mathrm{ha}^{-1}$ and fertilization $(\mathrm{PK}+)$ appeared to increase $\mathrm{N}$ mineralization of the mulch layer. There were, however, no significant treatment effects on the $\mathrm{C}: \mathrm{N}$ ratio $(P>0.10)$. In fact, assuming $\mathrm{C}$ is $50 \%$ of biomass, the mean $\mathrm{C}: \mathrm{N}$ ratio of the mulch at establishment was 88:1 while after 12 months it was 59:1, which in both cases is apparently too high for net $\mathrm{N}$ mineralization (Seneviratne 2000).

In an another slash and mulch study in Igarapé Açu, net losses from the mulch layer were 285, 75, 125 , and $16 \mathrm{~kg} \mathrm{ha}^{-1}$ of $\mathrm{N}, \mathrm{K}, \mathrm{Ca}$, and $\mathrm{Mg}$, respectively; however, $\mathrm{P}$ content increased by $11 \mathrm{~kg} \mathrm{ha}^{-1}$ after 18 months (Sá et al. 1998). In contrast, Kato et al. (1999) working in the same region reported decreases of up to $50 \%$ in the mulch layer for Mehlich-1 extractable $\mathrm{P}$ over 18 months in the absence of fertilizer. Baggie et al. (2004) observed that fertilizing mulch with $\mathrm{P}$ increased $\mathrm{P}$ extracted but not release of $\mathrm{P}$ from mulch residue. In the current study, observed gains in $\mathrm{P}$ and $\mathrm{K}$ mulch content in all treatments may have been the result of incorporation of mineral soil $\mathrm{P}$ through bioturbation or redistribution of dissolved fertilizer through ponded surface water. Increases in mulch $\mathrm{P}$ and $\mathrm{K}$ content ranged from 200 to $400 \%$ and 50 to $280 \%$, respectively, relative to the amount applied.

Despite some large changes in the mulch layer, only small differences in $0-20 \mathrm{~cm}$ soil $\mathrm{N}$ among treatments were observed. Response in soil-N to the presence of $\mathrm{N}_{2}$-fixers has been reported previously (Montagnini and Sancho 1994). Fertilization with $\mathrm{P}$ plus $\mathrm{K}$ also did not create consistent patterns in soil concentrations of these or other nutrients. The only significant response to fertilization in the main-plot treatment was a decrease in $\mathrm{Mg}$.

Plant growth of manioc and weeds accounted for an uptake of $100,26,58,50$, and $13 \mathrm{~kg} \mathrm{ha}^{-1}$ of $\mathrm{N}, \mathrm{P}, \mathrm{K}$, $\mathrm{Ca}$, and $\mathrm{Mg}$, respectively. The nutrient loss from mulch could account for this supply of $\mathrm{N}, \mathrm{Ca}$, and $\mathrm{Mg}$ but mulch was a sink for $\mathrm{P}$ and $\mathrm{K}$. The accumulation of $\mathrm{N}, \mathrm{Ca}$, and $\mathrm{Mg}$ in both trees and manioc generally increased in response to fertilization treatments with manioc also having higher $\mathrm{N}$ under the $\mathrm{N}_{2}$-fixer. Presently, there is conflicting evidence regarding increased $\mathrm{N}$ uptake by manioc with fertilization or in the presence of $\mathrm{N}_{2}$-fixers (Howeler 2002; Carsky and Toukourou 2005). In Colombia, foliar $\mathrm{N}$ concentrations of manioc did not respond to NPK fertilization but stems and tubers both had increased $\mathrm{N}$ concentrations (Howeler 2002). No increases for $\mathrm{N}$ content in stems or tubers between an unfertilized control and 60-16-138 N-P-K fertilization were reported in Benin, Africa (Carsky and Toukourou 2005); however, increases in $\mathrm{N}$ content were reported for whole-plant uptake with fertilization. Data presented here indicates that PK fertilization or presence of $\mathrm{N}_{2}$-fixers may increase $\mathrm{N}$ uptake by manioc. Nutrient contents of $\mathrm{P}, \mathrm{K}, \mathrm{Ca}$ and $\mathrm{Mg}$ also increased with fertilization and the presence of $I$. edulis. Increased uptake of $\mathrm{K}$ in response to $\mathrm{K}$ fertilization, which can be limiting to manioc, may have facilitated uptake of other nutrients.

Due to the absence of hand weeding during this study, as likely would have been carried out in a farmer's field, there was a relatively large amount of nutrient accumulation in weeds. Between 40 and $65 \mathrm{~kg} \mathrm{ha}^{-1}$ year $^{-1}$ of $\mathrm{N}$ accumulated in weeds. $\mathrm{N}$ concentration and contents of weeds increased in the presence of I. edulis. With fertilization, concentration tended to decline, although $\mathrm{N}$ contents still increased.

Phosphorus is typically considered to limit growth for agriculture in the eastern Amazon (Gehring et al. 1999) and Davidson et al. (2004) report an increase of $23 \%$ in foliar $\mathrm{P}$ concentrations with $\mathrm{N}$ and $\mathrm{P}$ fertilization. In this study there was a decrease of about $10 \%$ in foliar P concentrations of weedy vegetation. Accumulation of $\mathrm{P}$ in mulch was observed, and although this uptake is difficult to explain, it may limit plant available P. Measured cation contents all 
increased in response to fertilization with $\mathrm{P}$ plus $\mathrm{K}$ indicating that fertilization increases the rate at which weedy vegetation accumulates nutrients and could reduce nutrient availability to trees and crops.

\section{Conclusions}

Slash and mulch technologies combined with simultaneous AFS for native trees and manioc is an attractive alternative to slash and burn for sustaining soil productivity. In all cases, the cycling of nutrients through the mulch, including the incorporation of inorganic fertilizers during the first planting phase, should help sustain nutrient cycles. Of the native tree species utilized, the $\mathrm{N}_{2}$-fixer I. edulis had high survival in both fertilized and un-fertilized conditions and interplanting with $I$. edulis increased growth of C. pentandra, S. amazonicum, and manioc. However, I. edulis may compete with slower-growing heliophytes such as $C$. odorata, through shading, especially when fertilized, so might require pruning. As demonstrated in other research, one beneficial use of pruned material is to smother weeds and also to provide nutrients as a green manure. C. pentandra and $S$. amazonicum also performed well if released from light competition. After two years, several S. amazonicum exceeded $15 \mathrm{~m}$ in height with fertilization.

The greater growth demonstrated by trees and manioc coupled with elevated mortality of trees and manioc in the fertilized treatment indicate that synchronization of management techniques is needed. It may be advisable to fertilize only after the onset of the rainy season to avoid moisture stress and for trees and manioc to compete effectively against other vegetation. Given that fertilization caused significant increases in both manioc tuber yield and tree growth it may be an attractive allocation of available capital. Also, since only limited vegetation control was performed in this trial reported growth should represent the lowest expected values for a farmer in this region.

For the first two years of this project (Mar-05 to Jul-07) results demonstrated success with secondary forest mulching, establishment of $4 \mathrm{~m}$ wide mixedspecies tree plantings, and harvest of a crop of manioc after $\sim 20$ months (Jul-05 to Mar-07) as well as retention of the two-year-old trees (Jul-05 to Jul07) after harvest.

\section{References}

Alegre JC, Rao MR, Arevalo LA, Guzman W, Faminow MD (2005) Planted tree fallows for improving land productivity in the humid tropics of Perú. Agric Ecosyst Environ 110(1-2):104-117

Baggie I, Rowell DL, Robinson JS, Warren GP (2004) Decomposition and phosphorus release from organic residues as affected by residue quality and added inorganic phosphorus. Agrofor Syst 63:125-131

Blake GR, Hartge KH (1986) Bulk Density. In: Klute A (ed) Methods of soil analysis: part 1, 2nd edn. Soil Sci Soc Am Inc, Madison, WI, pp 383-412

Bremmer JM, Mulvaney CS (1982) Nitrogen-total. In: Page AL, Miller RH, Keeney DR (eds) Methods of soil analysis, part 2. Soil Sci Soc Am Inc, Madison, WI, pp 595-624

Brienza Jr S (1999) Biomass Dynamics of Fallow Vegetation Enriched with Leguminous trees in the Eastern Amazon of Brazil. PhD Dissertation, Georg-August-Univ, Göttingen, Germany

Browder JO, Pedlowski MA (2000) Agroforestry performance on small farms in Amazônia: findings from the Rondônia Agroforestry Pilot Project. Agrofor Syst 49:63-83

Camargo JLC, Ferraz IDK, Imakawa AM (2002) Rehabilitation of degraded areas of Central Amazônia using direct sowing of forest tree seeds. Restor Ecol 10(4):634-636

Carsky RJ, Toukourou MA (2005) Identification of nutrients limiting cassava yield maintenance on a sedimentary soil in southern Benin, West Africa. Nutr Cycl Agroeco 71:151-162

d'Oliveira MVN (2000) Artificial regeneration in gaps and skidding trails after mechanised forest exploitation in Acre, Brazil. For Ecol Manag 127(1):67-76

Davidson R, Gagnon D, Mauffette Y, Hernandez H (1998) Early survival, growth and foliar nutrients in native Ecuadorian trees planted on degraded volcanic soil. For Ecol Manag 105(1-3):1-19

Davidson EA, de Carvalho JR, Vieira ICG, Figueiredo RO, Moutinho P, Ishida FY, dos Santos MTP, Guerrero JB, Kalif K, Sabá RT (2004) Nitrogen and phosphorus limitation of biomass growth in a tropical secondary forest. Ecol Appl 14(4):S150-S163

Denich M, Vielhauer K, Kato MdA, Block A, Kato OR, Sá TDdA, Lücke W, Vlek PLG (2004) Mechanized land preparation in forest-based fallow systems: the experience from Eastern Amazônia. Agrofor Syst 61:91-106

El-Sharkawy MA (1993) Drought-tolerant cassava for Africa, Asia and the Americas. Bioscience 43(7):441

Gallagher RS, Fernandes ECM, McCallie EL (1999) Weed management through short-term improved fallows in tropical agroecosystems. Agrofor Syst 47:197-221

Gee GW, Bauder JW (1986) Particle-size analysis. In: Klute A (ed) Methods of soil analysis: part 1, 2nd edn. Soil Sci Soc Am Inc, Madison, WI, pp 383-412

Gehring C, Denich M, Kanashiro M, Vlek PLG (1999) Response of secondary vegetation in Eastern Amazonia to relaxed nutrient availability constraints. Biogeochem 45:223-241

Hoffman CA, Carroll CR (1995) Can we sustain the biological basis of agriculture? Annu Rev Ecol Syst 26:69-92 
Hölscher D (1997) Shifting cultivation in Eastern Amazonia: a case study on the water and nutrient balance. Plant Research and Development, vol Vol. 46. Institute for Science Co-operation, Tübingen, Federal Republic of Germany

Hossner LR (1996) Dissolution for total elemental analysis. In: Sparks DL (ed) Methods of Soil Analysis: Part 3. Soil Sci Soc Am Inc, Madison, WI, pp 49-64

Howeler RH (2002) Cassava mineral nutrition and fertilization. In: Hillocks RJ, Thresh JM, Belloti AC (eds) Cassava: biology, production and utilization. CAB International, Wallingford, UK, pp 115-147

Howeler RH, Cadavid LF (1983) Accumulation and distribution of dry matter and nutrients during a 12-month growth cycle of cassava. Field Crops Res 7:123-139

Jacobs DF, Rose R, Haase DL, Alzugaray PO (2004) Fertilization at planting impairs root system development and drought avoidance of Douglas-fir (Pseudotsuga menziesii) seedlings. Anna For Sci 61:643-651

Kato MSA, Kato OR, Denich M, Vlek PLG (1999) Fire-free alternatives to slash-and-burn for shifting cultivation in the eastern Amazon region: the role of fertilizers. Field Crops Res 62(2-3):225-237

Kato OR, Kato MSA, de Carvalho CR, Figueiredo R, Sá TDdA, Vielhauer K, Denich M (2005) Manejo de vegetação secundária na Amazônia visando ao aumento da sustentabilidade do uso agrícola do solo. XXX Congresso Brasileiro de Ciência do Solo. Recife, Brazil

Kettler JS (1997) Fallow enrichment of a traditional slash/ mulch system in southern Costa Rica: comparisons of biomass production and crop yield. Agrofor Syst 35: 165-176

Lorenzi H (2002) Árvores Brasileiras, Vol. 02, $2^{\text {a }}$ Edição. Instituto Plantarum de Estudos da Flora Ltda, Nova Odessa, SP, Brasil, p 368

Metzger JP (2002) Landscape dynamics and equilibrium in areas of slash-and-burn agriculture with short and long fallow period (Bragantina region, NE Brazilian Amazon). Landsc Ecol 17:419-431

Montagnini F, Sancho F (1994) Net nitrogen mineralization in soils under six indigenous tree species, an abandoned pasture and a secondary forest in the Atlantic lowlands of Costa Rica. Plant Soil 162(1):117-124

Moreira FMdS, da Silva MF, de Faria SM (1992) Occurrence of nodulation in legume species in the Amazon region of Brazil. New Phytol 121(4):563-570
Navarro C, Montagnini F, Hernández G (2004) Genetic variability of Cedrela odorata Linnaeus: results of early performance of provenances and families from Mesoamerica grown in association with coffee. For Ecol Manag 192(2-3):217-227

Nelson DW, Sommers LE (1996) Total carbon, organic carbon, and organic matter. In: Sparks DL (ed) Methods of soil analysis: part 3. Soil Sci Soc Am Inc, Madison, WI, pp 961-1010

Peck RB, Bishop JP (1992) Management of secondary tree species in agroforestry systems to improve production sustainability in Amazonian Ecuador. Agrofor Syst 17(1): 53-63

Peña-Claros M (2003) Changes in forest structure and species composition during secondary forest succession in the Bolivian Amazon. Biotropica 35(4):450-461

Pinedo-Vasquez M, Zarin DJ, Coffey K, Padoch C, Rabelo F (2001) Post-boom logging in Amazônia. Human Ecol 29(2):219-239

Rippin M, Haggar JP, Kass D, Köpke U (1994) Alley cropping and mulching with Erythrina poeppigiana (Walp.) O. F. Cook and Gliricidia sepium (Jacq.) Walp.: effects on maize/weed competition. Agrofor Syst 25(2):119-134

Sá TDdA, Vilhauer K, Kanashiro M, Denich M, Vlek PLG (1998) Towards improving natural resources in Eastern Amazônia through a modified sequential agroforestry system. II Congresso Brasileiro em Sistemas Agroflorestais, Belém

Salazar A, Szott LT, Palm CA (1993) Crop-tree interactions in alley cropping systems on alluvial soils of the Upper Amazon Basin. Agrofor Syst 22:67-82

Sanchez PA (1995) Science in agroforestry. Agrofor Syst 30:5-55

Seneviratne G (2000) Litter quality and nitrogen release in tropical agriculture: a synthesis. Bio Fert Soils 31:60-64

Stanley W, Montagnini F (1999) Biomass and nutrient accumulation in pure and mixed plantations of indigenous tree species grown on poor soils in the humid tropics of Costa Rica. For Ecol Manag 113(1):91-103

Yamada M, Gholz HL (2002) An evaluation of agroforestry systems as a rural development option for the Brazilian Amazon. Agrofor Syst 55:81-87

Zech W, Senesi N, Guggenberger G, Kaiser K, Lehmann J, Miano TM, Miltner A, Schroth G (1997) Factors controlling humification and mineralization of soil organic matter in the tropics. Geoderma 79:117-161 